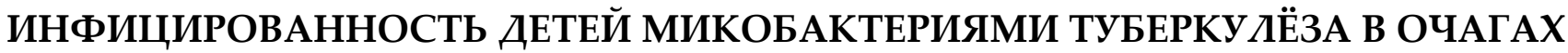 ТУБЕРКУ ЯЁЗНОЙ ИНФЕКЦИИ РЕСПУБЛИКИ ТАДЖИКИСТАН
}

\author{
О.И. БОБОХОДЖАЕВ ${ }^{1}$ У.Ю. СИРОДЖИДИНОВА ${ }^{1}$, С.М. САЙДАДИЕВ ${ }^{1}$, Р.С. БОЗОРОВА
}

${ }^{1}$ Кафедра фтизиопульмонологии, Таджикский государственный медицинский университет имени Абуали ибни Сино, Душанбе, Республика Таджикистан

2 Кафедра функциональной диагностики и клинической лаборатории, Таджикский Национальный университет, Душанбе, Республика Таджикистан

Цель: изучить уровень инфицированности детей микобактериями туберкулёза из очагов туберкулёзной инфекции Республики Таджикистан и влияние вакцинации БЦЖ при интерпретации туберкулинодиагностики.

Материал и методы: проанализированы результаты туберкулинодиагностики детей из очагов туберкулёзной инфекции в Республике Таджикистан: из города Бохтар ( $\mathrm{n=176)}$ и посёлка Дусти Хатлонской области ( $\mathrm{n}=124)$. При интерпретации результатов туберкулинодиагностики учитывали влияние вакцинации БЦЖ у детей в возрасте до 6 лет.

Результаты: положительный результат туберкулиновой пробы у детей 0-6 лет составил 64,7\%, у детей 7-14 лет - 47,0\% и у детей 15-17 лет $61,5 \%$. Установлено, что частота гиперергических реакций на туберкулин у детей в очагах туберкулёзной инфекции с возрастом увеличивается. Самый высокий уровень гиперергических реакций отмечается у детей в возрасте $15-17$ лет: в городе $-22,2 \%$, в селе - 27,3\% и в возрастной группе 7-14 лет: в городе - 20\%, в селе - 25\%. В возрастной же группе 0-6 лет этот показатель составил 2,4\% и 3\% соответственно.

Заключение: анализ показывает, что ситуация по туберкулёзу в очагах туберкулёзной инфекции, особенно в возрасте 7 лет и старше, сложная. Для правильной интерпретации туберкулинодиагностики у детей в возрасте до 6 лет важно учитывать влияние вакцинации Бцж. Отмечается высокий уровень инфицированности детей в очагах инфекции, что требует особого внимания и мер комплексной профилактики развития туберкулёза в очагах. Важным фактором позднего выявления больных детей с тяжёлыми и осложнёнными формами туберкулёза является факт недостаточного наблюдения за контактными детьми, проживающими в очагах туберкулёзной инфекции.

Ключевые слова: туберкулёз, очаг туберкулёзной инфекции, вакцинация БЦЖ, туберкулинодиагностика, подростковый возраст, инфицированность, заболеваемость.

Для цитирования: Бобоходжаев ОИ, Сироджидинова УЮ, Сайдалиев СМ, Бозоров РС. Инфицированность детей микобактериями туберкулёза в очагах туберкулёзной инфекции в Республике Таджикистан. Вестник Авиценны. 2021;23(2):235-41. Available from: https://doi.org/10.25005/2074-0581 2021-23-2-235-241

\section{PREVALENCE OF MYCOBACTERIUM TUBERCULOSIS AMONG CHILDREN AT THE RESERVOIRS OF INFECTION IN THE REPUBLIC OF TAJIKISTAN}

\author{
O.I. BOBOKHOJAEV' ${ }^{1}$, U.YU. SIRODJIDINOVA ${ }^{1}$, S.M. SAYDALIEV'1, R.S. BOZOROVA²
}

1 Department of Phthisiopulmonology, Avicenna Tajik State Medical University, Dushanbe, Republic of Tajikistan

2 Department of Functional Diagnostics and Clinical Laboratory, Tajik National University, Dushanbe, Republic of Tajikistan

Objective: To study the prevalence of Mycobacterium tuberculosis at the infection reservoirs in the Republic of Tajikistan among children and the impact of BCG vaccination assessed by tuberculin skin test.

Methods: The results of tuberculin skin test in children from Mycobacterium tuberculosis seedbeds in the Republic of Tajikistan were analyzed in the city of Bokhtar ( $n=176)$ and the village of Dusti, Khatlon region $(n=124)$. The impact of BCG vaccination in children under 6 years of age was considered in interpretation of the tuberculin skin test results.

Results: The positive result of the tuberculin skin test in children aged 0-6 years was found in $64.7 \%$ of cases, $7-14$ years - in $47.0 \%$ and $15-17$ years - in $61.5 \%$ respectively. It was shown that rate of high degree of tuberculin sensitivity in children from Mycobacterium tuberculosis reservoirs increased with age. The highest rate of tuberculin sensitivity was observed in $15-17$ years old children, and among them in the city $-22.2 \%$, in the village $-27.3 \%$; followed by the age group $7-14$ years: in the city $-20 \%$, in the village $-25 \%$. In the age group $0-6$ years, this indicator was $2.4 \%$ and $3 \%$ respectively. Conclusion: The analysis shows that the situation with tuberculosis in the reservoirs of infection, especially in children aged 7 years and over, is challenging. For the correct interpretation of tuberculin test results in children under 6 years of age, it is important to consider the effect of BCG vaccination. Prevalence of the tuberculosis among the children at the infection reservoirs is high, which requires special attention and measures for comprehensive prevention of tuberculosis in its seedbeds. Insufficient monitoring of contact children residing in the reservoirs of infection is an important factor contributing to the late detection of severe and complicated forms of tuberculosis in children.

Keywords: Tuberculosis, reservoirs of tuberculosis infection, BCG vaccination, tuberculin test, adolescence, infection, morbidity.

For citation: Bobokhojaev OI, Sirodjidinova UYu, Saydaliev SM, Bozorov RS. Infitsirovannost' detey mikobakteriyami tuberkulyoza v ochagakh tuberkulyoznoy infektsii v Respublike Tadzhikistan [Prevalence of Mycobacterium tuberculosis among children at the reservoirs of infection in the Republic of Tajikistan]. Vestnik Avitsenny [Avicenna Bulletin]. 2021;23(2):235-41. Available from: https://doi.org/10.25005/2074-0581-2021-23-2-235-241 


\section{ВВЕДЕНИЕ}

Туберкулёз (ТБ) в очагах туберкулёзной инфекции (ТБИ) остаётся актуальной проблемой и в XXI веке. По оценкам ВОЗ примерно одна треть населения инфицирована микобактерией ТБ, и есть риск развития этой болезни среди данной когорты. Заболеваемость в очагах ТБИ в 20-30 раз больше, чем в здоровом окружении [1]. Заболеваемость ТБ у детей из очагов ТБИ является важным эпидемиологическим показателем. При слабой организационной работе и не соблюдении мер инфекционного контроля по ТБ в очагах ТБИ риск инфицирования и развития заболевания ТБ детей и подростков остаётся высоким [2].

По оценкам ВОЗ в 2019 г. во всём мире ТБ заболели 10 миллионов человек, включая 5,6 миллионов мужчин, 3,2 миллиона женщин и 1,2 миллиона детей. По мнению многих авторов ситуация по ТБ осложняется, в связи с высоким распространением ВИЧ-инфекции и увеличением случаев химиорезистентного и, особенно, мультирезистентного ТБ [3].

Некоторые исследователи считают, что рост заболеваемости детей из очагов ТБИ указывает на слабо поставленную работу в очагах инфекции [4]. Исследования показали, что инфицированность детей в группах риска (сахарный диабет, воспалительные заболевания органов дыхания, часто болеющие дети и др.) составляет от 10,8 до 14,1\% [5]. Многие учёные считают, что без улучшения работы по раннему выявлению в очагах ТБИ стабилизация эпидемиологических показателей у детей невозможна [6-8]. Одна из основных причин поздней диагностики заболевания детей из очагов ТБИ - это слабая организационная работа в учреждениях первичной медико-санитарной помощи (ПМСП) и ТБ центрах по профилактике и раннему выявлению ТБ у контактных детей [9-13]. Контактные дети являются группой риска развития ТБ и нуждаются в тщательном обследовании в учреждениях ПМСП и частом мониторинге со стороны ТБ учреждений [9]. Аксёнова ВА с соавт (2017) отмечают, что заболеваемость детей 15-17 лет вдвое превышает заболеваемость детей 0-14 лет [14, 15].

Другие авторы считают, что риск развития заболевания, осложнённое течение и исход лечения ТБ у детей зависят от качества вакцинации БЦж, длительности контакта и качества проводимых мероприятий в очагах ТБИ [16]. Однако в этих работах не отмечена важность учёта влияния вакцинации БЦЖ при интерпретации результатов туберкулинодиагностики у детей в возрасте до 6 лет. Учёные из Национального медицинского исследовательского центра фтизиопульмонологии и инфекционных заболеваний России считают, что внедрение современных методов скринингового обследования детского населения на ТБ играет важную роль в ранней диагностике и улучшении эпидемической ситуации по ТБ среди населения [17].

Таким образом, проведение туберкулиновых проб, правильная их интерпретация с учётом влияния вакцинации БцЖ у детей в возрасте до 6 лет, выявление инфицированных детей и назначение превентивного противотуберкулёзного лечения снижают риск развития ТБ у детей $[18,19]$. В Республике Таджикистан данное исследование проводится впервые.

\section{ЦЕЛЬ ИССЛЕДОВАНИЯ}

Изучить уровень инфицированности детей микобактериями туберкулёза из очагов туберкулёзной инфекции Республики Таджикистан и влияние вакцинации БЦЖ при интерпретации туберкулинодиагностики.

\section{INTRODUCTION}

High prevalence of tuberculosis (TB) in the seedbeds of tuberculosis infection (TBI) remains an urgent medical problem in the 21st century. WHO estimates that approximately one third of population is infected with Mycobacterium tuberculosis, and there is a high risk of TB transmission in this cohort. Overall prevalence of TB in its reservoirs is 20-30 times higher than in a healthy environment [1]. The incidence of TB among children from the TBI seedbeds is an important epidemiological indicator. With poor management and non-compliance with infection control measures in the TBI reservoirs, the risk of infection transmission and TB development in children and adolescents remains high [2].

In 2019, WHO estimated that 10 million people worldwide suffer from TB, including 5.6 million men, 3.2 million women and 1.2 million children. According to many authors, the situation with TB is becoming more complicated due to the high prevalence of HIV infection and the growing number of cases of chemoresistant and, especially, multi-drug resistant TB [3].

Some researchers believe that the increase in the TB prevalence among children from TBI reservoirs indicates poorly organized work in the seedbeds of infection [4]. Studies have shown that the infection rate of children in risk groups (diabetes mellitus, inflammatory diseases of the respiratory system, frequently ill children, etc.) ranges from 10.8 to $14.1 \%$ [5]. Many scientists believe that without improvement of work on early detection of TB at the infection seedbeds, stabilization of epidemiological indicators in children is impossible [6-8]. One of the main reasons for the late diagnosis in children from TBI reservoirs is poor organizational work in primary health care facilities (PHC) and TB centers for the prevention and early detection of this infection in contact children [9-13]. Contact children are at risk of developing TB and require careful examination in primary care facilities and frequent monitoring [9]. Aksyonova VA et al (2017) note that the TB prevalence in adolescents aged $15-17$ is twice as high as in children aged 0-14 [14, 15].

Other authors believe that the risk of developing TB in children, the complicated course and outcome of treatment depend on the quality of BCG vaccination, the duration of contacts and the level of preventive measures taken in the TBI seedbeds [16]. However, in these studies the importance of consideration of the effect of BCG vaccination in interpretation of the results of tuberculin testing in children under 6 years of age is not emphasized. Scientists from the National Medical Research Center for Phthisiopulmonology and Infectious Diseases of Russia believe that introduction of modern methods of screening the childhood population for TB plays an important role in the early diagnosis and improvement of the epidemic situation with TB among the population [17].

Thus, tuberculin testing and its proper interpretation, consideration of the effect of BCG vaccination in children under 6 years of age, detection of infected children and prescription of preventive anti-tuberculosis treatment, reduce the risk of TB development in children $[18,19]$. This study is being conducted for the first time in the Republic of Tajikistan.

\section{Objective}

To study the prevalence of Mycobacterium tuberculosis among children from TB reservoirs in the Republic of Tajikistan 


\section{МАТЕРИАЛ И МЕТОДЫ}

Анализировались результаты туберкулинодиагностики детей из очагов ТБИ - жителей города и села. Из города Бохтар обследовано 176 и посёлка Дусти Хатлонской области - 124 человека. Все дети были разделены по возрасту на 3 группы: 0-6, 7-14 и 15-17 лет. Следует отметить, что в Таджикистане все дети на 3-5 день после рождения получают вакцину БЦж, при этом более 25 лет не проводится ревакцинация БЦЖ. В связи с этим, у детей старше 6 лет положительные результаты пробы Манту можно оценить как инфицированность, в то же время следует иметь в виду, что у детей 0-6 лет может иметь место влияние вакцины БЦЖ.

Статическая обработка материала производилась на ПК с использованием прикладного пакета IBM SPSS 23.0 (USA). Относительные величины были представлены в виде долей (\%), сравнительный анализ проведён с помощью определения критерия $\chi^{2}$ Пирсона, при снижении чисел менее 10 в одной из ячеек четырёхпольной таблицы учитывалась поправка Йетса, а при количестве наблюдений менее 5 использовался точный критерий Фишера. Для множественного сравнения применяли критерий $\chi^{2}$ для произвольных таблиц. Различия считались статистически значимыми при $\mathrm{p}<0,05$. and the effect of BCG vaccination on the interpretation of tuberculin tests results.

\section{METHODS}

The results of tuberculin tests in children from TBI seedbeds - city and village residents - were analyzed. Total of 176 people from the city of Bokhtar and 124 - from the village of Dusti, Khatlon region, were examined. All children were divided by age into 3 groups: 0-6 years old, 7-14 years old and 15-17 years old. It should be noted that in Tajikistan, all children at 3-5 days after birth get the BCG vaccine, while revaccination has not been done for more than 25 years. In this regard, positive results of the Mantoux test in children aged over 6 years can be considered as an infection, at the same time, it should be borne in mind that in children aged 0-6 years, this might be effect of the BCG vaccine.

Data analysis was performed using the IBM SPSS 23.0 application package (USA). The relative values were presented in the form of per cent (\%), the comparative analysis was carried out using Pearson $\chi^{2}$ criterion, with Yates correction applied if $n<10$ in

таблица 1 Результаты туберкулинодиагностики детей в очагах инфекции

\begin{tabular}{|c|c|c|c|c|c|c|c|c|c|}
\hline \multirow{3}{*}{$\begin{array}{l}\text { Возраст, } \\
\text { лет }\end{array}$} & \multirow{3}{*}{$\begin{array}{c}\text { Место } \\
\text { проживания }\end{array}$} & \multirow{2}{*}{\multicolumn{2}{|c|}{$\begin{array}{c}\text { Количество } \\
\text { обследованных }\end{array}$}} & \multicolumn{6}{|c|}{ Результат пробы } \\
\hline & & & & \multicolumn{2}{|c|}{ Отрицательный } & \multicolumn{2}{|c|}{ Сомнительный } & \multicolumn{2}{|c|}{ Положительный } \\
\hline & & всего & $\%$ & всего & $\%$ & всего & $\%$ & Bcero & $\%$ \\
\hline \multirow{3}{*}{$0-6$} & Село & 51 & 100 & 16 & 31,3 & 2 & 3,9 & 33 & 64,7 \\
\hline & Город & 65 & 100 & 17 & 26,1 & 6 & 9,2 & 42 & 64,6 \\
\hline & $\mathrm{p}$ & & & \multicolumn{2}{|c|}{$>0,05\left(\chi^{2}=0,4\right)$} & \multicolumn{2}{|c|}{$>0,05^{* *}\left(\chi^{2}=0,5\right)$} & \multicolumn{2}{|c|}{$>0,05\left(\chi^{2}=0,0\right)$} \\
\hline \multirow{3}{*}{$7-14$} & Село & 58 & 100 & 8 & 13,8 & 22 & 37,9 & 28 & 48,3 \\
\hline & Город & 75 & 100 & 17 & 22,6 & 23 & 30,7 & 35 & 46,7 \\
\hline & $p$ & & & \multicolumn{2}{|c|}{$>0,05^{*}\left(\chi^{2}=1,2\right)$} & \multicolumn{2}{|c|}{$>0,05\left(\chi^{2}=0,8\right)$} & \multicolumn{2}{|c|}{$>0,05\left(\chi^{2}=0,0\right)$} \\
\hline \multirow{3}{*}{$15-17$} & Село & 15 & 100 & 2 & 13,3 & 2 & 13,3 & 11 & 73,3 \\
\hline & Город & 36 & 100 & 11 & 30,5 & 7 & 19,4 & 18 & 50,0 \\
\hline & $p$ & & & \multicolumn{2}{|c|}{$>0,05 * *\left(\chi^{2}=0,3\right)$} & \multicolumn{2}{|c|}{$>0,05^{* *}\left(\chi^{2}=0,7\right)$} & \multicolumn{2}{|c|}{$>0,05\left(\chi^{2}=2,4\right)$} \\
\hline \multirow{3}{*}{ Всего } & Село & 124 & 100 & 26 & 20,9 & 26 & 20,9 & 72 & 58,0 \\
\hline & Город & 176 & 100 & 45 & 25,6 & 36 & 20,4 & 95 & 53,9 \\
\hline & $p$ & & & \multicolumn{2}{|c|}{$>0,05\left(\chi^{2}=0,9\right)$} & \multicolumn{2}{|c|}{$>0,05\left(\chi^{2}=0,0\right)$} & \multicolumn{2}{|c|}{$>0,05\left(\chi^{2}=0,5\right)$} \\
\hline
\end{tabular}

Примечания: $\mathrm{p}$ - статистическая значимость различий между селом и городом (по критерию $\chi^{2}$ Пирсона; ${ }^{*}$ - с поправкой Йетса; ** - по точному критерию Фишера)

Table 1 Results of tuberculin test in children from the infection reservoirs

\begin{tabular}{|c|c|c|c|c|c|c|c|c|c|}
\hline \multirow{3}{*}{ Age, years } & \multirow{3}{*}{ Residence } & \multirow{2}{*}{\multicolumn{2}{|c|}{$\begin{array}{l}\text { Number } \\
\text { examined }\end{array}$}} & \multicolumn{6}{|c|}{ Sample result } \\
\hline & & & & \multicolumn{2}{|c|}{ Negative } & \multicolumn{2}{|c|}{ Doubtful } & \multicolumn{2}{|c|}{ Positive } \\
\hline & & Total & $\%$ & Total & $\%$ & Total & $\%$ & Total & $\%$ \\
\hline \multirow{3}{*}{$0-6$} & Село & 51 & 100 & 16 & 31.3 & 2 & 3.9 & 33 & 64.7 \\
\hline & Город & 65 & 100 & 17 & 26.1 & 6 & 9.2 & 42 & 64.6 \\
\hline & $\mathrm{p}$ & & & \multicolumn{2}{|c|}{$>0.05\left(\chi^{2}=0.4\right)$} & \multicolumn{2}{|c|}{$>0.05 * *\left(\chi^{2}=0.5\right)$} & \multicolumn{2}{|c|}{$>0.05\left(\chi^{2}=0.0\right)$} \\
\hline \multirow{3}{*}{$7-14$} & Село & 58 & 100 & 8 & 13.8 & 22 & 37.9 & 28 & 48.3 \\
\hline & Город & 75 & 100 & 17 & 22.6 & 23 & 30.7 & 35 & 46.7 \\
\hline & $p$ & & & \multicolumn{2}{|c|}{$>0.05^{*}\left(\chi^{2}=1.2\right)$} & \multicolumn{2}{|c|}{$>0.05\left(\chi^{2}=0.8\right)$} & \multicolumn{2}{|c|}{$>0.05\left(\chi^{2}=0.0\right)$} \\
\hline \multirow{3}{*}{$15-17$} & Село & 15 & 100 & 2 & 13.3 & 2 & 13.3 & 11 & 73.3 \\
\hline & Город & 36 & 100 & 11 & 30.5 & 7 & 19.4 & 18 & 50.0 \\
\hline & $p$ & & & \multicolumn{2}{|c|}{$>0.05^{* *}\left(\chi^{2}=0.3\right)$} & \multicolumn{2}{|c|}{$>0.05^{* *}\left(\chi^{2}=0.7\right)$} & \multicolumn{2}{|c|}{$>0.05\left(x^{2}=2.4\right)$} \\
\hline \multirow{3}{*}{ Total } & Село & 124 & 100 & 26 & 20.9 & 26 & 20.9 & 72 & 58.0 \\
\hline & Город & 176 & 100 & 45 & 25.6 & 36 & 20.4 & 95 & 53.9 \\
\hline & $p$ & & & \multicolumn{2}{|c|}{$>0.05\left(\chi^{2}=0.9\right)$} & \multicolumn{2}{|c|}{$>0.05\left(\chi^{2}=0.0\right)$} & \multicolumn{2}{|c|}{$>0.05\left(\chi^{2}=0.5\right)$} \\
\hline
\end{tabular}

Notes: $p$ - statistical significance of differences between the village and the city (according to Pearson's $\chi^{2}$ test; * - with Yates' correction; ** - Fisher exact test) 


\section{РЕЗУЛЬТАТЫ И ИХ ОБСУЖДЕНИЕ}

Результаты туберкулиновых проб у детей из очагов ТБИ из города и села в зависимости от возраста приведены в табл. 1 .

Результаты исследования показывают, что в очагах ТБИ уровень инфицированности как в селе, так и в городе статистически не отличается. Самый высокий уровень инфицированности детей из очагов ТБИ, отмечается в подростковом возрасте.

В очагах ТБИ в городе у детей в подростковом возрасте уровень инфицированности составил 50\%, в возрасте 7-14 лет $46,7 \%$ и возрасте 0-6 лет - 64,6\%. Этот же показатель в сельской местности по возрастам составил 73,3\%, 48,3\% и 64,7\% соответственно.

Среди детей с положительным результатом на туберкулин оценивали уровень гиперергических реакций (табл. 2).

Анализ показывает, что гиперергические реакции как в селе, так и в городе увеличиваются с возрастом детей. Частота гиперергических реакций на туберкулинодиагностику у детей в очагах инфекции в возрастной группе 7-14 лет по сравнению с возрастной группой 0-6 лет в селе увеличиваются с $3 \%$ до $25 \%$ или в 8,3 раза, в городе - с 2,4\% до 20\% или в 8,1 раза. В возрасте 15-17 лет гиперергические реакции встречаются в селе у $27,3 \%$ и в городе - у 22,2\% обследованных.

таблица 2 Сравнительный анализ по гиперергическим реакциям one of the cells of the four-field table. When the number of observations is less than 5, Fisher's exact test was used. For multiple comparisons, the $\chi^{2}$ test for contingency tables was used. Differences were considered statistically significant at $p<0.05$.

\section{RESULTS AND DISCUSSION}

The results of tuberculin tests in children from seedbeds of TBI from cities and villages, depending on age, are shown in Table 1.

The results of the study show that in the seedbeds of TB, the level of infection both in the village and in the city does not differ statistically. The highest prevalence of infection among children from the TBI reservoir was noted in adolescence.

In the seedbeds of TBI in the city the infection rate was $50 \%$ among adolescents, $46.7 \%$ - at the age of $7-14$ years, and $64.6 \%$ - at the age of 0-6 years. In rural areas the same indicator by age was $73.3 \%, 48.3 \%$ and $64.7 \%$, respectively.

Among children with a positive result for tuberculin, the level of test's sensitivity was assessed (Table 2).

The analysis shows that the rate of highly sensitive tests both in the village and in the city community increases with the age of children. The prevalence of the tuberculin positive tests in children from the tuberculosis reservoir in the age group of 7-14

\begin{tabular}{|c|c|c|c|c|c|c|c|c|c|}
\hline \multirow{3}{*}{ Возраст, лет } & \multicolumn{4}{|c|}{ Результат по селу } & \multicolumn{4}{|c|}{ Результат по городу } & \multirow{3}{*}{$\mathbf{p}_{0}$} \\
\hline & \multicolumn{2}{|c|}{ Положительный } & \multicolumn{2}{|c|}{ Гиперергический } & \multicolumn{2}{|c|}{ Положительный } & \multicolumn{2}{|c|}{ Гиперергический } & \\
\hline & Bcero & $\%$ & Bcero & $\%$ & Bcero & $\%$ & Bcero & $\%$ & \\
\hline $0-6$ & 33 & 100,0 & 1 & 3,0 & 42 & 100,0 & 1 & 2,4 & $>0,05^{* *}\left(\chi^{2}=1,0\right)$ \\
\hline 7-14 & 28 & 100,0 & 7 & 25,0 & 35 & 100,0 & 7 & 20,0 & $>0,05^{*}\left(\chi^{2}=0,03\right)$ \\
\hline $15-17$ & 11 & 100,0 & 3 & 27,3 & 18 & 100,0 & 4 & 22,2 & $>0,05^{* *}\left(\chi^{2}=1,0\right)$ \\
\hline Всего & 72 & 100,0 & 11 & 15,2 & 95 & 100,0 & 12 & 12,6 & $>0,05\left(\chi^{2}=0,1\right)$ \\
\hline$p_{1}$ & \multicolumn{4}{|c|}{$=0,029\left(<0,05 ; \chi^{2}=7,1\right)$} & \multicolumn{4}{|c|}{$=0,028\left(<0,05 ; \chi^{2}=7,2\right)$} & \\
\hline
\end{tabular}

Примечания: $p_{0}$ - статистическая значимость различий показателей между значением детей из города и села (критерий $\chi^{2}$ Пирсона; * - с поправкой Йетса; ** - по точному критерию Фишера); $p_{1}$ - статистическая значимость различий показателей между возрастными группами (критерий $\chi^{2}$ для произвольных таблиц)

Table 2 Comparative analysis of high sensitivity response

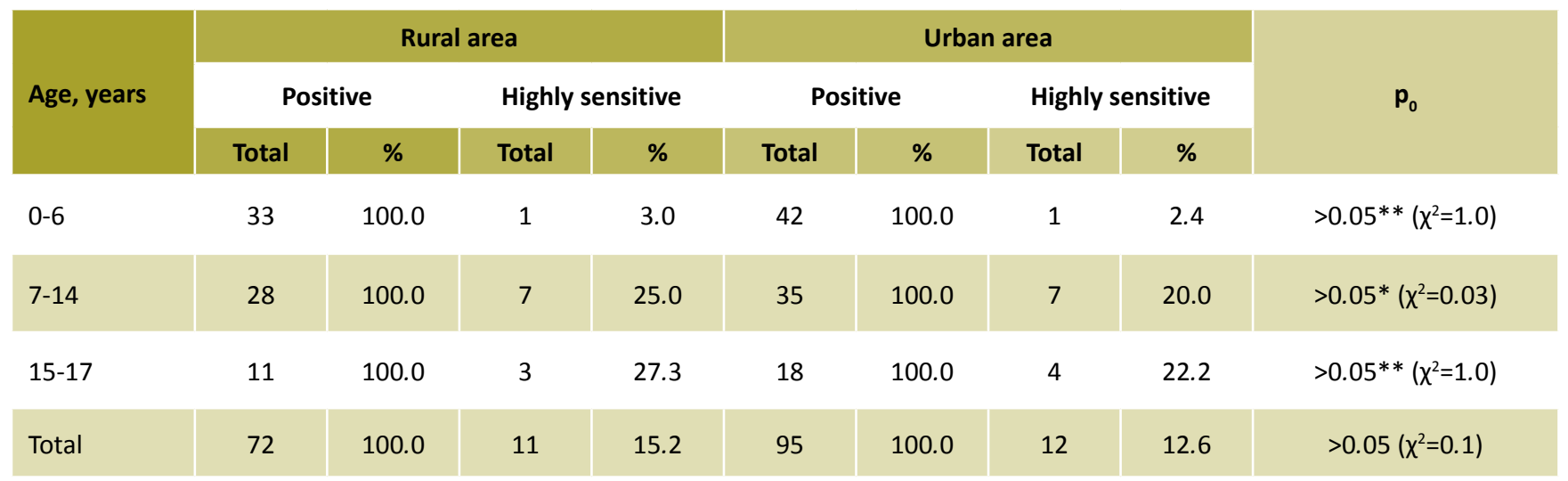

$\mathrm{p}_{1}$

$=0.029\left(<0.05 ; \chi^{2}=7.1\right)$

$=0.028\left(<0.05 ; \chi^{2}=7.2\right)$

Notes: $p_{0}$ - statistical significance of the differences in indicators between the urban and rural areas (Pearson $\chi^{2}$ test; ${ }^{*}-$ with Yates' correction, ${ }^{* *}-$ Fisher exact test); $\mathrm{p}_{1}$ - statistical significance of differences in indicators between age groups ( $\chi^{2}$ test for contingency tables) 
Учитывая тот факт, что в стране не проводится ревакцинация БЦЖ, рост положительных и гиперергических реакций у детей старше 6 лет говорит об инфицировании детей микобактериями ТБ.

\section{ЗАКЛЮЧЕНИЕ}

Таким образом, полученные результаты свидетельствуют о том, что в очагах туберкулёзной инфекции с увеличением возраста отмечается также и рост уровня инфицированности детей микобактериями туберкулёза. Самый высокий уровень инфицированности в очагах туберкулёзной инфекции отмечен у детей в возрастной группе $15-17$ лет (50\% в городе и 73,3\% в селе). Гиперергические реакции резко выросли в возрастной группе 7-14 лет по сравнению с возрастной группой 0-6 лет (в селе - в 8,3 раз и в городе - в 8,1 раз). Отмеченный высокий уровень инфицированности детей в очагах инфекции говорит о недостатках в наблюдении за контактными детьми и не соблюдении мер инфекционного контроля в очагах инфекции, что может привести к позднему выявлению больных детей с тяжёлыми и осложнёнными формами туберкулёза. При этом у детей в возрасте старше 6 лет при интерпретации результатов туберкулинодиагностики важно учитывать факт затихания действия вакцинации БцЖ. years was 8.3 times higher than in the age group 0-6 years in the village and 8.1 times - in the city. At the age of $15-17$ years high sensitivity of the tuberculin test was found in $27.3 \%$ of children in the city and $22.2 \%$ - in the village.

Considering the fact that BCG revaccination is not carried out in the country, the growth of positive and highly sensitive tests in children over 6 years of age indicates that the children are infected with Mycobacterium tuberculosis.

\section{CONCLUSION}

Thus, the results obtained indicate that in the tuberculosis infection seedbeds the prevalence of the disease increases with age. The highest infection rate in tuberculosis reservoirs is noted in children aged $15-17$ years $(50 \%$ in the city and $73.3 \%$ in the village). Frequency of highly sensitive tests increased significantly in the children aged 7-14 years compared with the age group of $0-6$ years (in the village -8.3 times and in the city -8.1 times). The noted high level of infection in children at the tuberculosis seedbeds indicates poor monitoring of contact children and non-compliance with infection control measures in tuberculosis reservoirs, which can lead to late detection of the infected children with severe and complicated forms of tuberculosis. At the same time, in children over the age of 6 years interpretation of the results of tuberculin tests need to consider attenuation of the BCG vaccination effect.

\section{ЛИТЕРАТУРА}

1. Аксёнова ВА, Барышникова ЛА, Клевно НИ. Современные подходы к скринингу туберкулёзной инфекции у детей и подростков в России. Медицинский совет. 2018;4:30-5. Available from: https://doi. org/10.14412/2074-2711-2018-4-30-35

2. Нечаева ОБ. Социально-значимые инфекционные заболевания, представляющие биологическую угрозу населению России. Туберкулёз и болезни лёгких. 2019;97(11):7-17. Available from: https://doi.org/10.21292/20751230-2019-97-11-7-17

3. Белогорцева ОИ, Шехтер ИЕ, Доценко ЯИ, Андреева ЕГ, Грыць ЛГ. Туберкулёз у детей на Украине. Туберкулёз и болезни лёгких. 2014;8:20-1.

4. Зоркальцева ЕЮ, Пугачёва СВ, Толстых АС. Медико-социальная характеристика больных туберкулёзом детей в условиях социального неблагополучия в Иркутской области. Acta Biomedica Scientifica. 2017;2:5-2:147-50.

5. Аксёнова ВА, Барышникова ЛА, Севостьянова ТА, Клевно НИ. Туберкулёз у детей в России и задачи фтизиатрической и общей педиатрической службы по профилактике и раннему выявлению заболевания. Туберкулёз и болезни лёгких. 2014;3:64-73. Available from: https://doi. org/10.21292/2075-1230-2014-0-3-64-73

6. Аксёнова ВА, Клевно НИ, Кавтарашвили СМ, Казаков АВ, Пахлавонова АД. Очаг туберкулёзной инфекции как риск развития у детей туберкулёза с множественной лекарственной устойчивостью. Туберкулёз и болезни лёгких. 2018;96(1):11-7. Available from: https://doi.org/10.21292/20751230-2018-96-1-11-17

7. Аксёнова ВА, Клевно НИ, Кавтарашвили СМ. Очаг туберкулёзной инфекции и его значение в развитии туберкулёза у детей. Туберкулёз и болезни лёгких. 2015;1:19-24. Available from: https://doi.org/10.21292/2075-12302015-0-1-19-24

\section{REFERENCES}

1. Aksyonova VA, Baryshnikova LA, Klevno NI. Sovremennye podkhody k skriningu tuberkulyoznoy infektsii u detey i podrostkov v Rossii [Modern approaches to the screening of tuberculosis infection in children and adolescents in Russia]. Meditsinskiy sovet. 2018;4:30-35. Available from: https://doi. org/10.14412/2074-2711-2018-4-30-35

2. Nechaeva OB. Sotsial'no-znachimye infektsionnye zabolevaniya, predstavlyayushchie biologicheskuyu ugrozu naseleniyu Rossii [Socially significant infectious diseases that pose a biological threat to the population of Russia]. Tuberkulyoz i bolezni lyogkikh. 2019;97(11):7-17. Available from: https://doi. org/10.21292/2075-1230-2019-97-11-7-17

3. Belogortseva OI, Shekhter IE, DotsenkoYal, Andreeva EG, Gryts LG. Tuberkulyoz $u$ detey na Ukraine [Tuberculosis in children in Ukraine]. Tuberkulyoz i bolezni lyogkikh. 2014;8:20-1.

4. Zorkal'tseva EYu, Pugachyova SV, Tolstykh AS. Mediko-sotsial'naya kharakteristika bol'nykh tuberkulyozom detey v usloviyakh sotsial'nogo neblagopoluchiya $v$ Irkutskoy oblasti [Medical and social characteristics of children with tuberculosis in conditions of social disadvantage in the Irkutsk region]. Acta Biomedica Scientifica. 2017;2:5-2:147-50.

5. Aksyonova VA, Baryshnikova LA, Sevostyanova TA, Klevno NI. Tuberkulyoz u detey v Rossii i zadachi ftiziatricheskoy i obshchey pediatricheskoy sluzhby po profilaktike i rannemu vyyavleniyu zabolevaniya [Childhood tuberculosis in russia, goals of the TB service and general pediatric service for TB prevention and early detection]. Tuberkulyoz i bolezni lyogkikh. 2014;3:40-6. Available from: https://doi.org/10.21292/2075-1230-2014-0-3-64-73

6. Aksyonova VA, Klevno NI, Kavtarashvili SM, Kazakov AV, Pakhlavonova AD. Ochag tuberkulyoznoy infektsii kak risk razvitiya u detey tuberkulyoza $\mathrm{s}$ mnozhestvennoy lekarstvennoy ustoychivost'yu [The nidus of tuberculous infection as a risk factor of multiple drug resistant tuberculosis in children]. Tuberkulyoz i bolezni lyogkikh. 2018;96(1):11-7. Available from: https://doi. org/10.21292/2075-1230-2018-96-1-11-17

7. Aksyonova VA, Klevno NI, Kavtarashvili SM. Ochag tuberkuleznoy infektsii i ego znachenie $v$ razvitii tuberkulyoza $u$ detey [The focus of tuberculosis infection and its importance in the development of tuberculosis in children]. Tuberkulyoz i bolezni lyogkikh. 2015;1:19-24. Available from: https://doi. org/10.21292/2075-1230-2015-0-1-19-24 
8. Фирсова ВА. Туберкулёз у подростков. Москва, РФ: ПТП «Типография «Наука»; 2010. 34 с.

9. Овсянкина ЕС, Панова ЛВ, Полуэктова ФА, Хитева АЮ, Виечелли ЕА. Актуальные проблемы туберкулёза у подростков из очагов туберкулёзной инфекции. Туберкулёз и болезни лёгких. 2018;96(6):17-20. Available from: https://doi.org/10.21292/2075-1230-2018-96-6-17-20

10. Сангинов АБ, Ализаде СГ, Латифов МД, Укуматшоева Лш. Туберкулёз у детей из очагов инфекции и частота его выявления. Здравоохранение Таджикистана. 2017;2:48-52.

11. Турдумамбетова ГК, Галиева РШ, Байтелиева АК. Скрининг латентной туберкулёзной инфекции у детей младшего школьного возраста. Вестник Академии медицинских наук Таджикистана. 2018;8(3):369-75.

12. Шахгельдян КИ, Гельцер БИ, Емцева ЕД, Середа ВГ, Мазелис ЛС, Сахарова ОБ. Анализ влияния социально-экономических факторов на эпидемическую ситуацию по туберкулёзу в регионах Российской Федерации. Проблемы социальной гигиены, здравоохранения и истории медицины. 2018;26(2):78-82. Available from: https://doi.org/10.18821/0869866X-2018-26-2-78-82

13. Бородулина ЭВ, Суслин СА. Современные особенности и тенденции эпидемиологии туберкулёза в Самаре. Проблемы социальной гигиены, здравоохранения и истории медицины. 2018;26(3):182-5. Available from: https://doi.org/10.18821/0869-866X-2018-26-3-182-185

14. Аксёнова ВА, Леви ДТ, Александрова НВ, Кудлай ДА, Барышникова ЛА, Клевно НИ. Туберкулёз у детей: современные методы профилактики и ранней диагностики. Доктор.Ру. 2017;15:9-15.

15. Аксёнова ВА, Стерликов СА, Белиловский ЕМ, Казыкина ТН. Эпидемиология туберкулёза у детей. Современные проблемы здравоохранения и медицинской статистики. 2017;3:102-38.

16. Мордик AB, Цыганова ЕA, Пузырёва ЛВ, Турица АА. Туберкулёз у детей Российской Федерации на современном этапе. Педиатрическая фармакология. 2014;11(3):27-30.

17. Ахмерова ТЕ, Бородулина ЕА, Чижонкова ЕБ. Особенности диагностики туберкулёза у детей с бактериовыделением. Туберкулёз и болезни лёгких. 2015;6:17-8

18. Аксёнова ВА, Клевно НИ, Казаков АВ, Кудлай ДА, Севостьянова ТА, Дементьева ЕК. Превентивное противотуберкулёзное лечение снижает риск развития локальных форм туберкулёза у детей, получающих иммуносупрессивную терапию: ретроспективное когортное исследование. Вопросы современной педиатрии. 2020;19(5):346-51. Available from: https://doi. org/10.15690/vsp.v19i5.2210

19. Аксёнова ВА, Клевно НИ, Казаков АВ, Фатыхова РX, Гордина АВ. Превентивная химиотерапия у детей из очагов туберкулёза с множественной лекарственной устойчивостью возбудителя. Туберкулёз и болезни лёгких. 2019;97(6):36-43. Available from: https://doi.org/10.21292/2075-1230-201997-6-36-43
8. Firsova VA. Tuberkulyoz u podrostkov [Tuberculosis in adolescents]. Moscow, RF: PTP "Tipografiya "Nauka"; 2010. 34 p.

9. Ovsyankina ES, Panova LV, Poluektova FA, Khiteva AYu, Viechelli EA. Aktual'nye problemy tuberkulyoza u podrostkov iz ochagov tuberkulyoznoy infektsii [Actual issues of tuberculosis in adolescents exposed to tuberculosis infection]. Tuberkulyoz i bolezni lyogkikh. 2018;96(6):17-20. Available from: https://doi. org/10.21292/2075-1230-2018-96-6-17-20

10. Sanginov AB, Alizade SG, Latiphov MJ, Ukumatshoeva LSh. Tuberkulyoz u detey iz ochagov infektsii i chastota ego vyyavleniya [Tuberculosis in children from the focus of infection and the frequency of its detection]. Zdravookhranenie Tadzhikistana. 2017;2:48-52.

11. Turdumambetova GK, Galieva RSh, Beytelieva AK. Skrining latentnoy tuberkulyoznoy infektsii u detey mladshego shkol'nogo vozrasta [Screening of latent tuberculosis infection in children of primary school age]. Vestnik Akademii meditsinskikh nauk Tadzhikistana. 2018;8(3):369-75.

12. Shakhgeldyan KI, Geltser BI, Emtseva ED, Sereda VG, Mazelis LS, Sakharova OB. Analiz vliyaniya sotsial'no-ekonomicheskikh faktorov na epidemicheskuyu situatsiyu po tuberkulyozu v regionakh Rossiyskoy Federatsii [The analysis of social economic factors impact on epidemic situation with tuberculosis in regions of the Russian Federation]. Problemy sotsial'noy gigieny, zdravookhraneniya $i$ istorii meditsiny. 2018;26(2):78-82. Available from: https://doi.org/10.18821/0869-866X-2018-26-2-78-82

13. Borodulina EV, Suslin SA. Sovremennye osobennosti i tendentsii epidemiologii tuberkulyoza v Samare [The modern characteristics and trends of tuberculosis epidemiology in Samara]. Problemy sotsial'noy gigieny, zdravookhraneniya $i$ istorii meditsiny. 2018;26(3):182-5. Available from: https://doi. org/10.18821/0869-866X-2018-26-3-182-185

14. Aksyonova VA, Levi DT, Aleksandrova NV, Kudlay DA, Baryshnikova LA, Klevno NI. Tuberkulyoz u detey: sovremennye metody profilaktiki i ranney diagnostiki [Tuberculosis in children: modern methods of prevention and early diagnosis]. Doktor.Ru. 2017;15:9-15.

15. Aksyonova VA, Sterlikov SA, Belilovskiy YEM, Kazykina TN. Epidemiologiya tuberkulyoza u detey [Epidemiology of tuberculosis in children]. Sovremennye problemy zdravookhraneniya i meditsynskoy statistiki. 2017;3:102-38.

16. Mordik AV, Tsyganova YEA, Puzyryova LV, Turitsa AA. Tuberkulyoz u detey Rossiyskoy Federatsii na sovremennom etape [Tuberculosis in children of the Russian Federation at the present stage]. Pediatricheskaya farmakologiya. 2014;11(3):27-30.

17. Akhmerova TE, Borodulina EA, Chizhonkova EB. Osobennosti diagnostiki tuberkulyoza u detey s bakteriovydeleniem [Features of the diagnosis of tuberculosis in children with bacterial excretion]. Tuberkulyoz i bolezni lyogkikh. 2015;6:17-8.

18. Aksyonova VA, Klevno NI, Kazakov AV, Kudlay DA, Sevostyanova TA, Dementyeva EK. Preventivnoe protivotuberkulyoznoe lechenie snizhaet risk razvitiya lokal'nykh form tuberkulyoza u detey, poluchayushchikh immunosupressivnuyu terapiyu: retrospektivnoe kogortnoe issledovanie [Preventive anti-tuberculosis treatment reduces the risk of developing localized forms of tuberculosis in children receiving immunosuppressive therapy]. Voprosy sovremennoy pediatrii. 2020;19(5):346-51. Available from: https://doi.org/10.15690/vsp.v19i5.2210

19. Aksyonova VA, Klevno NI, Kazakov AV, Fatykhova RKh, Gordina AV. Preventivnaya khimioterapiya u detey iz ochagov tuberkulyoza s mnozhestvennoy lekarstvennoy ustoychivost'yu vozbuditelya [Preventive chemotherapy in children from multidrug-resistant tuberculosis foci]. Tuberkulyoz i bolezni lyogkikh. 2019;97(6):36-43. Available from: https://doi.org/10.21292/2075-1230-2019$97-6-36-43$

\section{(i) СВЕДЕНИЯ ОБ АВТОРАХ}

Бобоходжаев Октам Икрамович, доктор медицинских наук, доцент, профессор кафедры фтизиопульмонологии, Таджикский государственный медицинский университет им. Абуали ибни Сино

Scopus ID: 55841885300

ORCID ID: 0000-0002-8619-3426

SPIN-код: 6745-5078

Author ID: 275977

E-mail: bobokhojaev@mail.ru

\section{(i) Author information}

Bobokhojaev Oktam Ikramovich, Doctor of Medical Sciences, Associate Professor, Professor of the Department of Phthisiopulmonology, Avicenna Tajik State Medical University

Scopus ID: 55841885300

ORCID ID: 0000-0002-8619-3426

SPIN: 6745-5078

Author ID: 275977

E-mail: bobokhojaev@mail.ru 
Сироджидинова Умринисо Юсуповна, доктор медицинских наук, профессор, профессор кафедры фтизиопульмонологии, Таджикский государственный медицинский университет им. Абуали ибни Сино

ORCID ID: 0000-0002-2981-8362

SPIN-код: 1802-3224

E-mail: umrinisso@yandex.ru

Сайдалиев Саъдулло Махмадалиевич, кандидат медицинских наук, заведующий кафедрой фтизиопульмонологии, Таджикский государственный медицинский университет им. Абуали ибни Сино

ORCID ID: 0000-0002-4462-9471

E-mail: saidalievs@mail.ru

Бозорова Рухшона Сайфуддиновна, кандидат медицинских наук, ассистент кафедры функциональной диагностики и клинической лаборатории, Таджикский национальный университет

ORCID ID: 0000-0002-9931-7723

E-mail: bozorovar@mail.ru

Информация об источнике поддержки в виде грантов, оборудования, лекарственных препаратов

Финансовой поддержки со стороны компаний-производителей лекарственных препаратов и медицинского оборудования авторы не получали

Конфликт интересов: отсутствует

\section{АДРЕС ДЛЯ КОРРЕСПОНДЕНЦИИ}

\section{Бобоходжаев Октам Икрамович}

доктор медицинских наук, доцент, профессор кафедры фтизиопульмонологии, Таджикский государственный медицинский университет им. Абуали ибни Сино

734003, Республика Таджикистан, г. Душанбе, пр. Рудаки, 139

Тел.: +992 (779) 995433

E-mail: bobokhojaev@mail.ru

\section{ВКЛАД АВТОРОВ}

Разработка концепции и дизайна исследования: БОИ, СУю

Сбор материала: БОИ

Статистическая обработка данных: СУЮ, ССМ

Анализ полученных данных: СУЮ, ССМ

Подготовка текста: БОИ, БРС

Редактирование: БОИ, БРС

Общая ответственность: БОИ
Sirodjidinova Umriniso Yusupovna, Doctor of Medical Sciences, Full Professor, Professor of the Department of Phthisiopulmonology, Avicenna Tajik State Medical University

ORCID ID: 0000-0002-2981-8362

SPIN: 1802-3224

E-mail: umrinisso@yandex.ru

Saydaliev Sadullo Makhmadalievich, Candidate of Medical Sciences, Head of the Department of Phthisiopulmonology, Avicenna Tajik State Medical University

ORCID ID: 0000-0002-4462-9471

E-mail: saidalievs@mail.ru

Bozorova Rukhshona Sayfuddinovna, Candidate of Medical Sciences, Assistant, Department of Functional Diagnostics and Clinical Laboratory, Tajik National University

ORCID ID: 0000-0002-9931-7723

E-mail: bozorovar@mail.ru

Information about support in the form of grants, equipment, medications

The authors did not receive financial support from companies manufacturing medications and medical equipment

Conflicts of interest: The authors have no conflicts of interest

\section{ADDRESS FOR CORRESPONDENCE:}

\section{Bobokhojaev Oktam Ikramovich}

Doctor of Medical Sciences, Associate Professor, Professor of the Department of Phthisiopulmonology, Avicenna Tajik State Medical University

734003, Republic of Tajikistan, Dushanbe, Rudaki Ave., 139

Tel.: +992 (779) 995433

E-mail: bobokhojaev@mail.ru

AUTHOR CONTRIBUTIONS

Conception and design: $\mathrm{BOI}, \mathrm{SUY}$

Data collection: $\mathrm{BO}$

Statistical analysis: SUYu, SSM

Analysis and interpretation: SUYu, SSM

Writing the article: $\mathrm{BOI}, \mathrm{BRS}$

Critical revision of the article: $\mathrm{BO}, \mathrm{BRS}$

Overall responsibility: $\mathrm{BO}$

Accepted 25.06.21

$\begin{array}{llll}\text { Поступила } & 31.03 .21 & \text { Submitted } & 31.03 .21 \\ \text { Принята в печать } & 25.06 .21 & \text { Accepted } & 25.06 .21\end{array}$

